\title{
USER ENVIRONMENT PERCEPTION IN HMD-BASED IMMERSIVE VIRTUAL REALITY CONTEXT
}

\author{
PERCEPÇÃO AMBIENTAL DE USUÁRIOS UTILIZANDO DISPOSITIVOS IMERSIVOS DE \\ REALIDADE VIRTUAL
}

\author{
Pedro Sávio Jobim Pinheiro1 \\ Dheila Walbe Ornstein ${ }^{2}$ \\ (D) Alessandra Rodrigues Prata \\ Shimomura ${ }^{3}$ \\ ${ }^{1}$ University of São Paulo, São Paulo, SP, \\ Brazil, savio.jobim@gmail.com \\ 2 University of São Paulo, São Paulo, SP, \\ Brazil, sheilawo@usp.br \\ 3 University of São Paulo, São Paulo, SP, \\ Brazil, arprata@usp.br
}

\begin{abstract}
Authors' contribution:
PSJP: conceptualization, data curation, formal analysis, investigation, methodology, validation, visualization, writing - original draft, writing - reviewing and editing. SWO: formal analysis, methodology, supervision, validation, writing - reviewing and editing. ARPS: formal analysis, methodology, supervision, validation, writing - reviewing and editing

Funding: National Council for Scientific and Technological Development. Conflict statement: nothing has been declared.
\end{abstract}

Responsible Editor: Letícia de Oliveira Neves (iD

\begin{abstract}
Advances in Virtual Reality (VR) technologies have enhanced the possibility of including this tool in design review procedures intuitively for users. This exploratory research investigates the users' perception of spatial dimensions and apparent surface temperature in HMD-based Immersive Virtual Environments (HIVE). It aims to raise new questions in the study of VR technologies during design evaluation procedures. The case study consisted of modelling the Pinacoteca building north atrium in São Paulo, Brazil, in VR to assess how users perceive the room according to its dimensions and sense of surface temperature (floor, walls, footbridges, elevators and roof). This exploratory study was conducted with 40 first-time visitors at the Pinacoteca building. The results revealed that users' immediate position and viewpoint may induce different perceptions of spatial dimensions and sense of surface temperature. The first conclusion is that instant distance to viewpoint influenced users' perception of width of the immersive virtual environment. The second conclusion was that virtual insolation influenced users' sense of surface temperature despite the materiality. To sum up, the contribution of this paper is the associative study of spatial perception and sense of surface temperature with instant position and viewpoint of users immersed in HIVE.
\end{abstract}

Keywords: virtual reality, design review, user perception.

\begin{abstract}
Resumo
O desenvolvimento de tecnologias de Realidade Virtual (RV) tornou possível a inclusão desta ferramenta em procedimentos mais intuitivos de avaliação de projetos de arquitetura com base na opinião dos usuários. Esta pesquisa exploratória tem por objetivo investigar a percepção dos usuários em ambientes virtuais imersivos (HIVE) baseados em dispositivos visualmente acoplados (DVAs), tendo como foco a percepção de dimensões espaciais e a sensação de temperatura superficial. O caso de estudo consistiu na modelagem do átrio norte do edifício da Pinacoteca em São Paulo em RV para analisar como os usuários avaliam o ambiente de acordo com suas dimensões e como as superfícies do átrio induzem os usuários a ter sensações de temperatura superficial aparente (piso, paredes, passarelas, elevadores e telhado). Este estudo exploratório foi realizado com 40 visitantes pela primeira vez no edifício da Pinacoteca. Os resultados revelaram que a posição e o ponto de vista imediatos dos usuários no momento em que são questionados podem induzir a diferentes respostas acerca de dimensões espaciais e aparente temperatura de superfícies. A primeira conclusão é que a distância do usuário à superfície observada no momento da pergunta influenciou a percepção dos usuários sobre a largura da sala modelada virtualmente. A segunda conclusão foi de que a insolação virtualmente simulada influenciou a sensação dos usuários sobre a suposta temperatura de superfície. A contribuição deste artigo refere-se, portanto, à associação entre a percepção espacial e a sensação de temperatura de superfície com a posição instantânea e ponto de vista de usuários imersos no HIVE.
\end{abstract}

Palavras-chave: realidade virtual, avaliação de projeto, percepção dos usuários.

How to cite this article:

PINHEIRO, P. S. J.; ORNSTEIN, S. W.; SHIMOMURA, A. R. P.. User environment perception in HMD-based immersive virtual reality context. PARC Pesquisa em Arquitetura e Construção, Campinas, SP, v. 12, p. e021031, 2021. DOI:

http://dx.doi.org/10.20396/parc.v12i00.8664335 


\section{Introduction}

Throughout the architectural design process, design review procedures are required to achieve better results in architectural projects. Nevertheless, end-users are not often included in the design process in early design review phases (BULLINGER et al., 2010). This situation commonly leads to failure in attempting users' expectations after the construction phase, as shown in many Post-Occupancy Evaluation (POE) appliances (ONO et al. 2018).

An example of an evaluation method tested to enhance communication between the designer and client during early design phases was conducted by Shen et al. (2013). The study applied Building Information Modeling (BIM), user activity simulation, and requirement management techniques to develop a Pre-Design Evaluation Method (PD) and demonstrated that systematic procedures conducted with end-users lead to wider participation compared to traditional approaches.

An effective way of including end-users in design review procedures is to use VR to produce Immersive Virtual Environments (IVE). It allows an intuitive approach towards aspects to be evaluated (KOUTSABASIS et al., 2012) even when compared to other traditional design tools (SOUZA; IMAI; AZUMA, 2013). This intuitive approach is a result of the combination of immersion and interaction. Freitas and Ruschel (2010) describe immersion as the feeling of being inside a virtual environment, while interaction is the machine's ability to detect user movement inputs. Florio and Tagliari (2016) compared two-dimensional drawings as a static representation of the space, similar to a photograph, which captures an "action" at a given moment in time, while threedimensional immersive models include time in spatial perception.

Several studies have been conducted using VR technologies in architecture, engineering, and construction. Zhang et al. (2020) quantitatively identified the main research themes and outcomes related to the use of VR technologies in Architecture, Engineering and Construction (AEC). Among the bibliographic results, the first group of studies considers VR as a tool for simulating built environments. For these studies, VR is usually considered as being an undoubtedly close technology to the physical environment after a meticulous calibration of camera, viewports, lighting characteristics and virtual textures and often use VR as a tool studying other subjects.

In the field of spatial perception of users in IVE, Cha et al. (2020) conducted a study to understand users' spatial perception of ceiling heights and variation in an HMD-based Immersive Virtual Environment (HIVE). The results show that the participants had distinctive spatial perceptions in the HIVE, reflecting variations in experimental conditions and resembling those in the real world.

In the field of lighting, Chamilothori et al. (2019) investigated daylight behaviour in an IVE impact of facade geometry and sunlight patterns on users' perception by comparing subjective questionnaires with physiological responses (heart rate and skin conductance). After conducting a study with 72 participants, facade and sunlight pattern geometry affected heart rate responses: there was a greater decrease in the heart rate of users exposed to an irregular facade compared to users exposed to traditional blinds.

Heydarian, Gerber, and Becerik-Gerber (2015) also investigated human behaviour towards lighting and how users prefer to balance artificial and natural light in a room by using IVE as a research tool. The experiment results showed a significant difference between those users that had only a semi-automatic control system to control the shades. In contrast, those given semi-automatic control options for both the artificial 
lights and shades did not have the same tendency. Again, the IVE support was a realistic tool to simulate an existing built environment based on previous research conducted by Dunston et al. (2011). Moreover, Carneiro, Aryal, and Becerik-Gerber (2019) used IVE as a tool for simulating feedback systems (energy consumption and lighting distribution) to avoid wasteful human behaviours. Developed with 80 participants immersed in IVE, it concluded that effective feedback systems could help drive users' behaviour towards desired outcomes.

Analogously, studies in the urban domain also consider the correlation between virtual and physical versions as a starting point to study morphological and behavioural studies. Shushan, Portugali, and Blumenfeld-Lieberthal (2016) established a correlation between urban morphology and how humans perceived the built environment by comparing homogeneous and heterogeneous urban environments projected in an IVE and the results of 26 participants' spatial perception. The outcome is that heterogeneous urban contexts provide higher informative and better imageability than homogeneous environments, considering that IVE represents a highly realistic version of the built environment. Fisher-Gewirtzman (2016) conducted a study where 40 participants were exposed to visual stimuli. Their route decisions were recorded to evaluate the effect of urban visibility on pedestrian route choices. The results were that the participants' routes were influenced by the visibility and stimuli of the urban environment.

The second group of studies assume VR technologies as the object of study itself as a tool for architectural design review. In this group, research aimed to study the usability, characteristics, behavior, influences of the VR technologies in design review, usually comparing $\mathrm{VR}$ or other design assessment tools to a real version of a certain variable.

Heydarian, Gerber, and Becerik-Gerber (2015) compared everyday office-related activities in both IVE and physical environments to test whether IVEs are adequate representations of physical environments. After analyzing the experimental data from 112 participants, the authors concluded that they performed similarly in an IVE setting to what they did in the physical environment for all analyzed tasks. The outcome demonstrates that an IVE can be an effective tool for design review and enhance enduser performance feedback.

Other studies, such as Yeom, Choi, and Kang (2019), investigated the effect of IVE characteristics on a sample of 16 participants' environmental sensations compared to the effect of a built indoor environment. The study measured participants' seven skin areas, and the outcome demonstrated that the participants mostly generated higher skin temperature in IVE. In addition, users' thermal perception assessed by a thermal sensation survey was significantly higher in the IVE condition than in the built environment.

In the field of usability, Klerk et al. (2019) conducted a study of HIVE in an early architectural design process. They concluded that the system is easier to use in a design review process and more effective than Computer-Aided Design (CAD) software to create simplified models quickly.

Renner, Velichkovsky, and Helmert (2013) depict the perception of apparent egocentric distances in HIVE. This review survey suggests that the final results reported that HIVE has accounted for a certain amount of distance compression ( $74 \%$ of the modeled distances) of users' subjective egocentric distance from the actual distance and arranged the possible factors into four groups: measurement methods, technical factors, compositional factors, and human factors. On the other hand, Paes, Arantes, and Irizarry (2017) also remember that distance perception in physical environments is not perfectly accurate, based on Witmer and Sadowski Jr (1998), in which human 
distance is human perception is $8 \%$ shorter than physical measures. Another study conducted by Kuliga et al. (2015) with 23 participants investigated the similarities between their evaluation of virtual and real versions of the same room. Even though few statistically significant differences between real and virtual building ratings were found, qualitative data revealed differences related to atmospherics.

A third set considers VR as a group of technologies and compares different VR technologies or IVE modelling procedures. For these studies, the usability of different VR technologies and the sense of presence are often analyzed.

The first main base of comparison is between immersive, and non-immersive VR supports. Even though Faas et al. (2014) indicated no correlations between the immersive tendency and designers' performance, this experiencing VR is widely recommended by other studies. A comparison between IVE and traditional screenbased VR was developed by Paes, Arantes, and Irizarry (2017). In this study, users' spatial perception using a conventional workstation was compared to those in IVE. The results indicated that IVE represented an overall better spatial perception among the 30 participants. This research compared the panoramic screen as the immersive environment, and it strongly recommended immersive forms of experiencing VR instead of traditional workstation versions.

Concerning the stage of development of IVEs, Oliveira (2003) compared a simplified version (using standard shading and render preview) and a realistic animation. It was observed that the simplified digital animation presents a satisfactory cost-benefit ratio in order to obtain design understanding for both the user and designer.

The sense of presence is also an investigation of Schubert (2003) that compared different VR technologies according to the users' feeling of "being there" and found out that HIVE is more efficient in this aspect when compared to screen-based VR representations. Suppose this last study was released in 2006, and the HIVE technology had its greatest development period during 2012-2013. In that case, it is expected that the differences are now even higher between these VR representations.

Many studies have been conducted using VR technologies in the field of AEC. Some studies have considered VR a tool for simulating other aspects of the built environment, such as lighting or spatial dimensions. In contrast, others have considered it a tool to be compared to other representation methods, such as technical drawings or physical models.

Schubert (2003) identified that HIVE is the VR most effective technology to make users feel like they are in a real room. Therefore, this study aims to investigate how users perceive the dimensions of a room when immersed in HIVEs and how the same users may be inducted to feel thermal sensations in a visual-only immersive technology. Even though there have been studies investigating how users perceive dimensions on a HIVE, there has been not much investigation on how users' perception of spatial dimensions correlates to their immediate position and target viewpoint.

In addition, the studies that had HIVEs as the main discussion topic have limited their contribution to visual-only discussions, not considering that vision is a key element to induct thermal sensations or impressions (LAM et al., 2020). Considering that a user's sense of temperature is not only a single correlation to the actual physical temperature but also influenced by visual stimuli (LAM et al., 2020)., the sense of surface temperature by users is also extremely important to understand how users evaluate a virtual room in VR. So, this study also aims to investigate how the users' perception of spatial 
dimensions and sense of surface temperature in HIVE correlates to their immediate position and target viewpoint when the question is made.

\section{Method}

An exploratory study was carried out with 40 volunteers immersed in a virtual version of the northern internal atrium of the Pinacoteca building to assess this virtual environment according to its dimensions and sense of surface temperature. As a strategic methodological approach, the same 40 volunteers were asked to evaluate the actual physical north atrium right after the virtual simulation. This method was able to identify to which extend the virtual and the correlated physical rooms were similar or different, according to their dimensions and sense of surfaces' temperature.

This experiment was approved by the Ethic Review Board of the School of Arts, Science and Humanities at the University of São Paulo by the certificate of ethics appreciation number 0000704818.2.0000.5390. Moreover, before the experiment began, each volunteer participant signed a consent form with a detailed explanation of procedures, as well as contact information of the authors in case they declined to take part in the research.

The case study: North atrium of Pinacoteca Building

The chosen case study was the north atrium of the Pinacoteca building. The Pinacoteca building was the first art museum in São Paulo and was originally designed in 1897 by Ramos de Azevedo. It underwent a major architectural renovation conducted by the architects Paulo Mendes da Rocha, Eduardo Colonelli and Weliton Ricoy during 19941999. The old courtyards were transformed into inner atriums, and crossing footbridges were constructed, changing the building's main axis of circulation (AIDAR; CHIOVATO, 2020). The results of the behavioral maps and flow maps developed by Pinheiro (2020) reveal that the atrium is an articulation space of the museum, with dimensions of $22.6 \mathrm{~m}$ $\mathrm{x} 9.4 \mathrm{~m}$ and a height of $17.4 \mathrm{~m}$, serving as a passage for most visitors.

Simulation workflow

Based on 2D plans and sections of the museum, the north atrium was modeled in Trimble Sketchup modelling software (https://www.sketchup.com/). To isolate the evaluation subject, only the atrium and perimeter corridors were included to prevent users from walking off the assessment zone. The furniture was also reproduced according to the actual benches of the atrium. The virtual textures of the floor, walls, footbridges, elevator and roof were generated based on images of the existing atrium to reproduce the visual aspects of the existing materials.

For rendering and concluding the graphic work, the model was exported to the Unreal Engine 4 (https://www.unrealengine.com/) with no dimension changes by using the 3D Exporter extension plugin, which ensures the original dimensions and texture qualities of the Trimble Sketchup model. In Unreal Engine 4, the chosen template was the "firstperson mode", allowing the user to freely move around the room by physically walking or handling the Oculus Touch motion-tracked controllers. The three main steps of the modelling are depicted in Figure 1.

The time and date of the model were set up for São Paulo $\left(23^{\circ} \mathrm{S}\right)$ at $2 \mathrm{pm}$ on February 10th 2019, which is compatible with the time the study was conducted, and the textures were enhanced by a bump and displacement adjustments. Finally, the camera was adjusted to $50 \mathrm{~mm}$, and the eye-level was set up at 1.70 meters, based on the author's height. 
PINHEIRO, P. S. J.; ORNSTEIN, S. W.; SHIMOMURA, A. R. P.

User environment perception in HMD-based immersive virtual reality context

Figure 1 - Three main steps of the modelling process. 1. Original $2 \mathrm{~d}$-drawing in .dwg extension used as a starting point to model a 3D room (left). 2. Digital model of the north atrium in. skp extension, based on the original plans and sections of the building (center). 3. Virtual model exported to Unreal Engine and ready to be used as an immersive model (right)
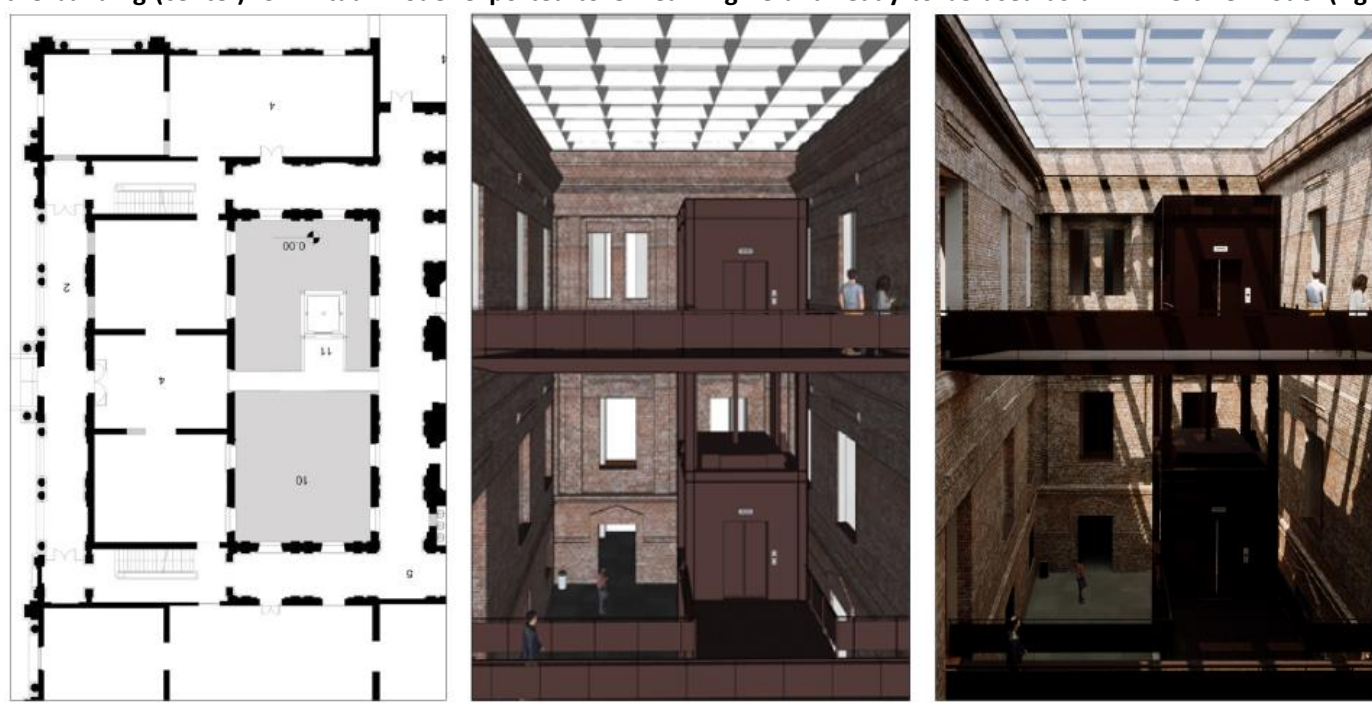

Source: Adapted from Pinheiro (2020).

The connection with Oculus Rift CV1 resulted in a HIVE with realistic features as shown in Figure 2.

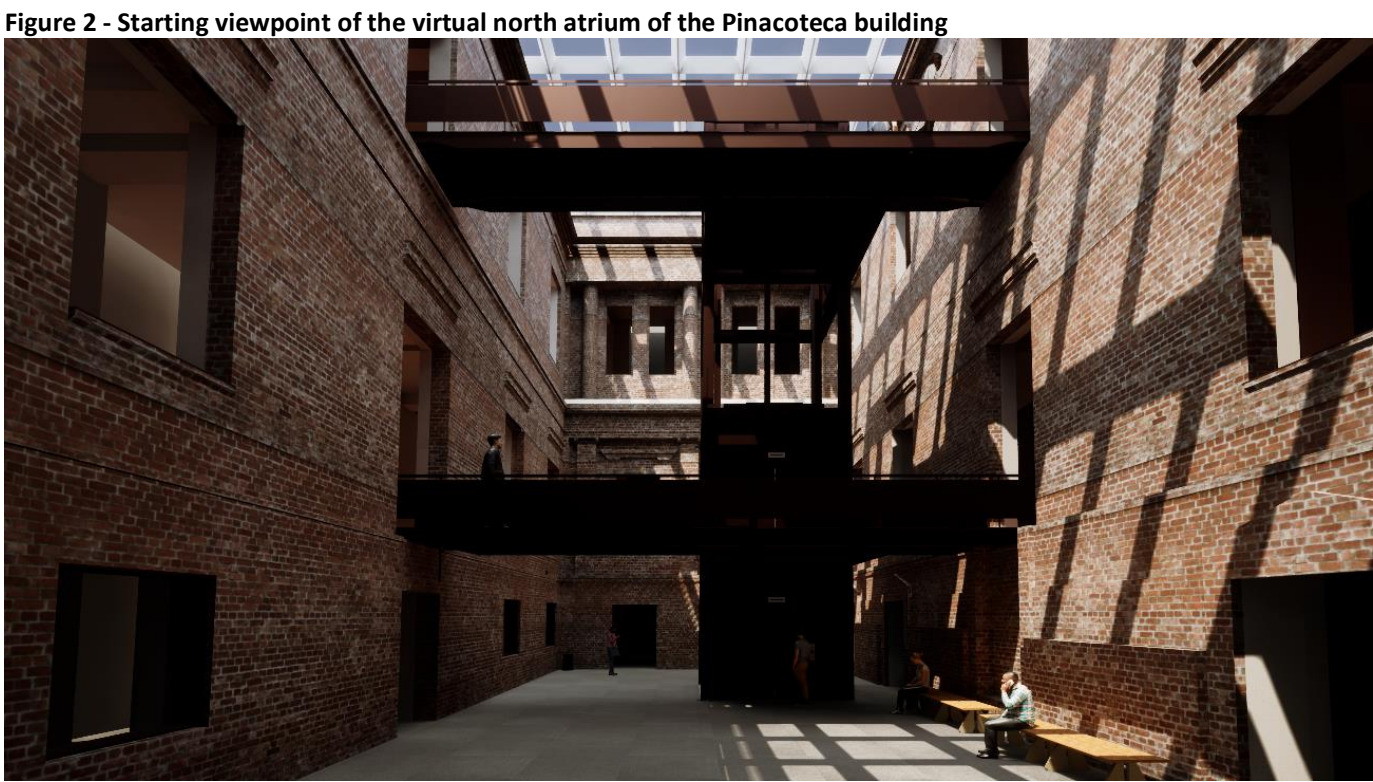

Source: Pinheiro (2020).

The user's starting point was placed in one of the main access points of the atrium, as depicted. The HIVE technology was applied based on previous studies, which demonstrated that it had one of the best outcomes in resemblance to the built environment (PAES; ARANTES; IRIZARRY, 2017).

\section{Questionnaires}

The users' perception of spatial dimensions and surface temperature in HIVE were obtained by verbal questionnaires divided into five sections. The first section focused on the demographic characteristics of the users, which consisted of two questions to assess the gender and educational level of the participants. The second question aimed to assess the spatial perception, and the last part aimed to obtain the users' impressions about the surfaces' apparent temperature. 
In the second section, participants were asked to evaluate their impressions of the virtual atrium's height, width, and length. The questions were developed on a five-scale basis as follows:

- Height: Very low, low, average, high, very high;

- Width: Very narrow, narrow, average, large and very large;

- Length: Very short, short, average, long and very long.

The questions in the third section were also developed on a five-scale basis (very cold, cold, average, warm, very warm) for the floor, walls, footbridge/elevator and roof materials. Due to problematic mapping of the footbridge/elevator and roof materials, these variables were not considered for this study.

\section{Equipment set up}

To avoid latency, the study used a recommended computer by Oculus (https://www.oculus.com/), which is an i5, GTX1050 with 64GB RAM notebook. The VR equipment was an Oculus Rift CV1, composed of an HMD (Resolution 2160x1200 or $1080 \times 1200$ pixels per eye, Pentile AMOLED, $90 \mathrm{~Hz}$ ), two Oculus touch motion-tracked controllers and two position-tracking sensors. After calibrating the HMD and positiontracking sensor settings, the available physical space for the participants was virtually registered, and the HMD was connected to Unreal Engine to render the virtual environment.

\section{Participants}

The study was conducted with 40 volunteer participants selected based on a brief eligibility questionnaire. Due to the manufacturer's recommendations and ethic board approvals, the selected participants were all adults from 18 up to 60 years old with fullcolour vision and overall health conditions. The volunteers were also mandatory to be first-time visitors to the Pinacoteca building to participate in the research, thus ensuring that they had no previous experience in the existing building. The last eligibility aspect was not to work in the AEC industry to avoid eventual professional biases (CIALONE; TENBRINKS; SPIERS, 2018; JULEAN, 2016).

\section{Procedures}

The procedures with participants at the Pinacoteca building took place between February $2^{\text {nd }}$ and $24^{\text {th }}, 2019$. The research station was positioned in the hall before the existing north atrium. Before starting the procedures, participants had a brief explanation about the study. They also read and signed a consent form. The detailed procedures are described in Figure 3.

The study was made in individual sessions of approximately 10 minutes. The first part of the experiment was to answer demographic questions about gender and educational level. Male (72\%) and graduates (68\%) represented the majority of the participants. The authors provided Disposable protection masks and helped with Interpupillary Distance (IPD) calibrations.

A brief tutorial was given to exemplify how HMD and motion controllers work, and immediate usability questions were made before the architectural design review. Thus, users were asked to move around the atrium and look in any direction to test the HMD. No cases of discomfort or technical problems were identified among the 40 participants. The traditional Simulator Sickness Questionnaire (SSQ) or the recently suggested Virtual reality sickness questionnaire (VRSQ), created by Kim et al. (2018), were replaced by two questions: "Do you feel any discomfort?" and "Does the HMD fit 
well in your head?". Only $8 \%$ of the participants answered that they had any discomfort with the HMD. Those participants were asked not to continue with the experiment.

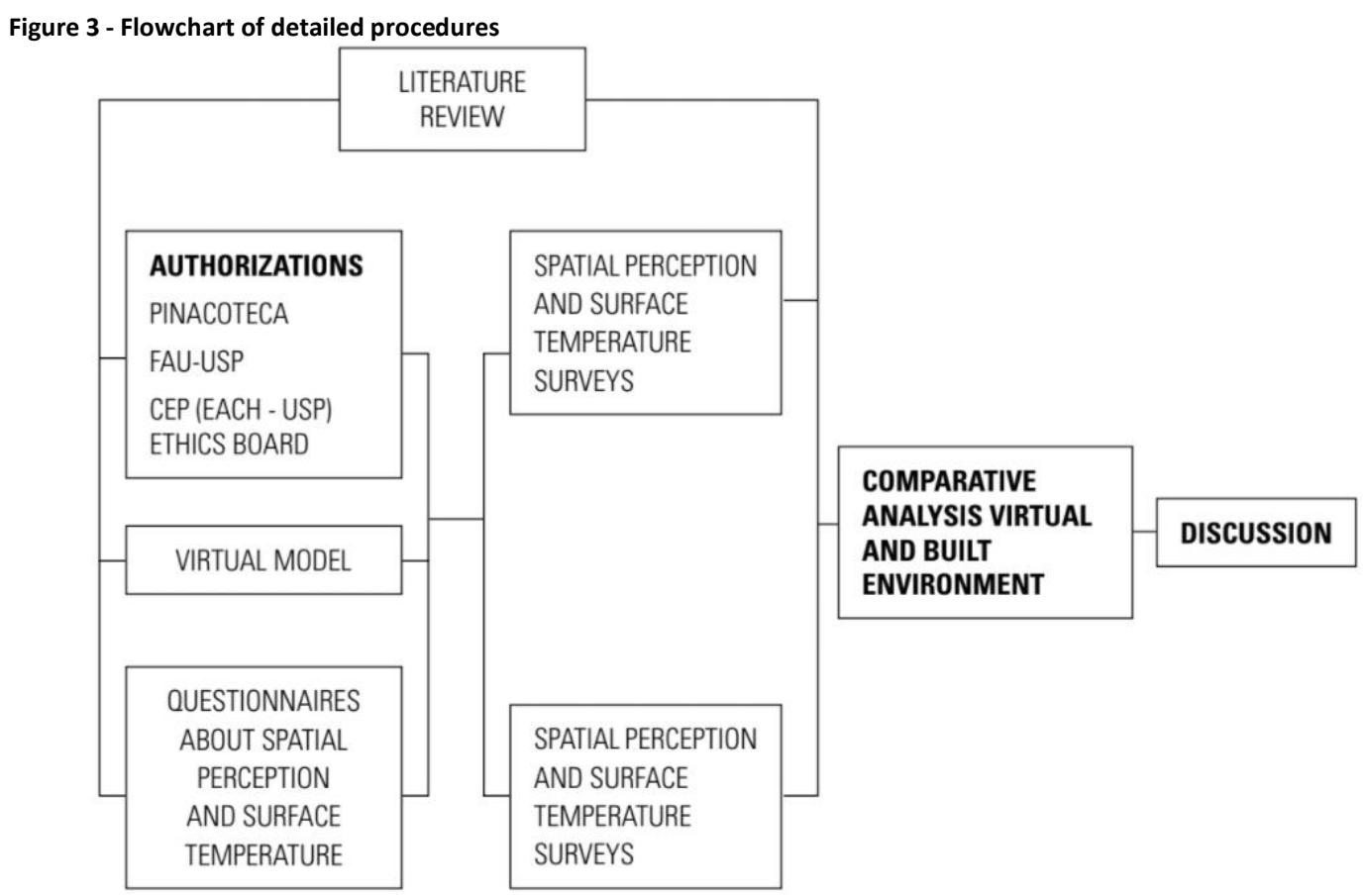

Source: Pinheiro (2020).

Once participants had answered the demographic and usability questions, they were asked to answer the verbal questionnaire concerning the architectural design of the virtual north atrium of the Pinacoteca building. This questionnaire included their impressions on height, width and length of the virtual atrium and their sense of surface temperature. Both sections were based on the five-scale base described previously. A usability question was made to check if the user felt any discomfort after using the HMD. Again, no problematic cases were reported. The equipment was sterilized after each individual session.

The last procedure was a resemblance questionnaire. Instead of using the traditional questionnaires to measure the users' sense of presence, such as the Igroup Presence Questionnaire (IPQ) (SCHUBERT, 2003), the same participants were asked to walk to the actual built north atrium at the Pinacoteca building to evaluate the similarity and differences between the virtual and the actual built version of the north atrium. No problematic cases were identified during the procedures and the data processing were conducted using Google Forms and Microsoft Excel.

\section{Results}

This paper investigated the users' perception of spatial dimensions and surface temperature in HMD-based Immersive Virtual Environments (HIVE). No significant correlation was found between gender and spatial nor surface temperature perception ( $p>0.05)$. Similarly, no correlation was found between the educational level and the same analyzed topics. Therefore, in the following section, the results of the applied questionnaires are presented together with possible effects of differences in users' perceptions. 


\section{Spatial perception}

Even though the participants could move through the IVE, significant differences were found in the correlation to the position and target viewpoint of the users at the time they were questioned about their perception of spatial dimensions.

Responses were mapped based on user position and target viewpoint. The room was divided into two zones for classification based on the central footbridges, as in Figure. 4. Participants positioned in the same zone as their target viewpoints were classified as "same-zone". In contrast, participants positioned in areas opposite their target viewpoints were classified as "different zones", as exemplified in Figure 5.

Figure 4 - Virtual North atrium, zones and examples of same-zoning target points - green - and different-zoning target points - red

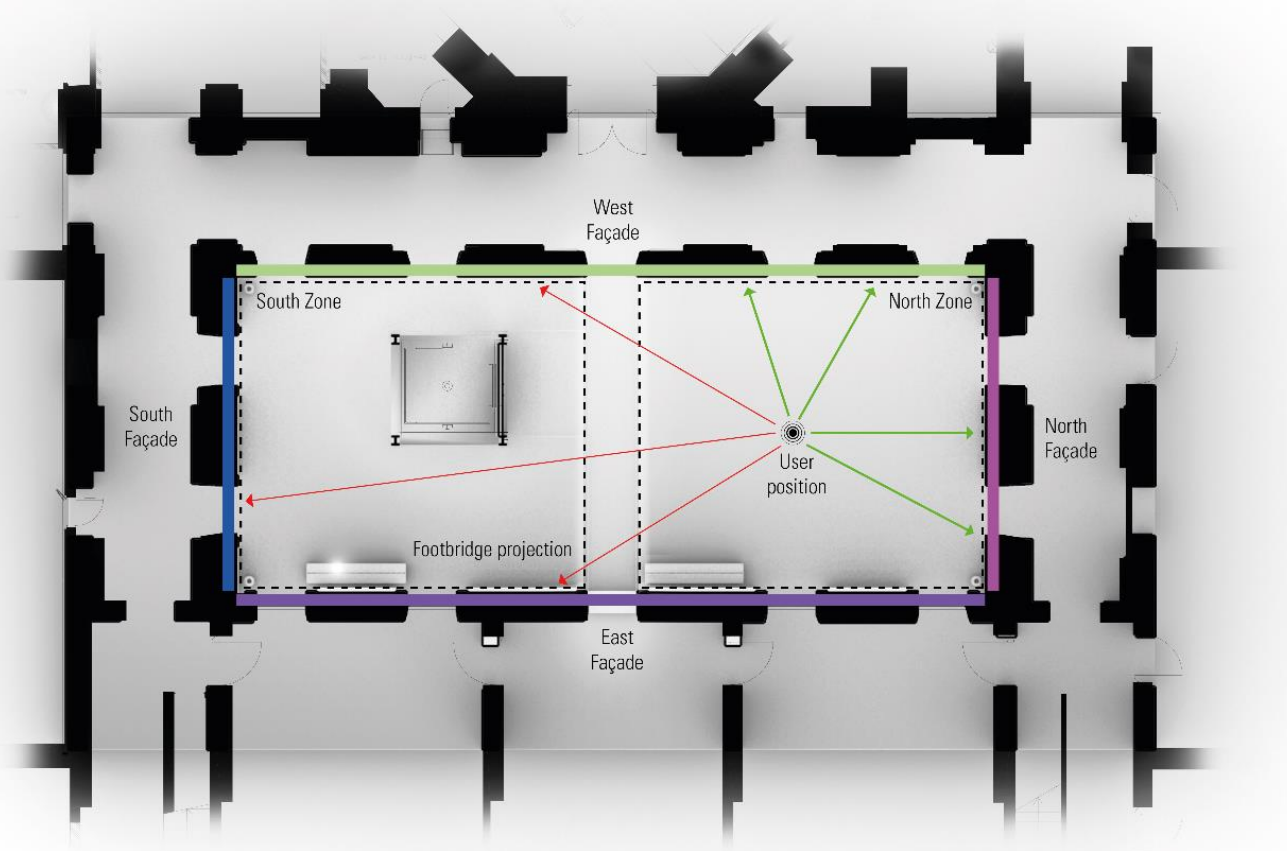

Source: Source: Pinheiro (2020).

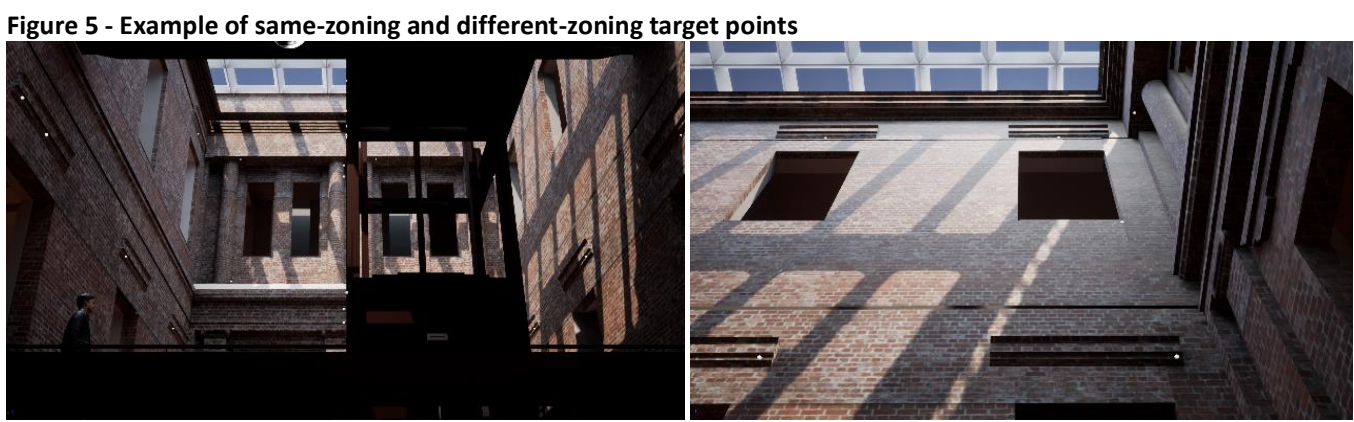

Source: Pinheiro (2020).

When questioned about their perception of the virtual north atrium length, users positioned in the same zone as their target viewpoint tended to classify the room as "shorter", "larger", and "higher" than those located in different zones as their target viewpoint.

As a result, $71.4 \%$ of the participants located in the same zone as their target viewpoint at the time of the question classified the atrium as "long". In comparison, the same 
evaluation increased to $88.5 \%$ in the sample of participants located in areas other than their target viewpoints. Contrarily, users who perceived the virtual north atrium as a "short" room decreased from $14.3 \%$ to $3.5 \%$ from participants in the same zone as their viewpoint to those in different zones. No answer was given from the five-scale classification bar for "very short" or "very long".

Similarly, the differences of perception were also observed in the width evaluation, as shown in Figure 6. Among the participants in the same zone as their target viewpoint, the room was classified as a "large" room for $80 \%$ of the respondents, whereas only $10 \%$ classified it as a "narrow" room. The difference was significant compared to the participants located in a different zone to their target viewpoint. Unlike the first ones, only $34.8 \%$ of these participants classified the room as "large", and $47.8 \%$ evaluated the same virtual room as "narrow".

Figure 6 - Evaluation of the width of the virtual north atrium according to the position and target viewpoint. 40 respondents

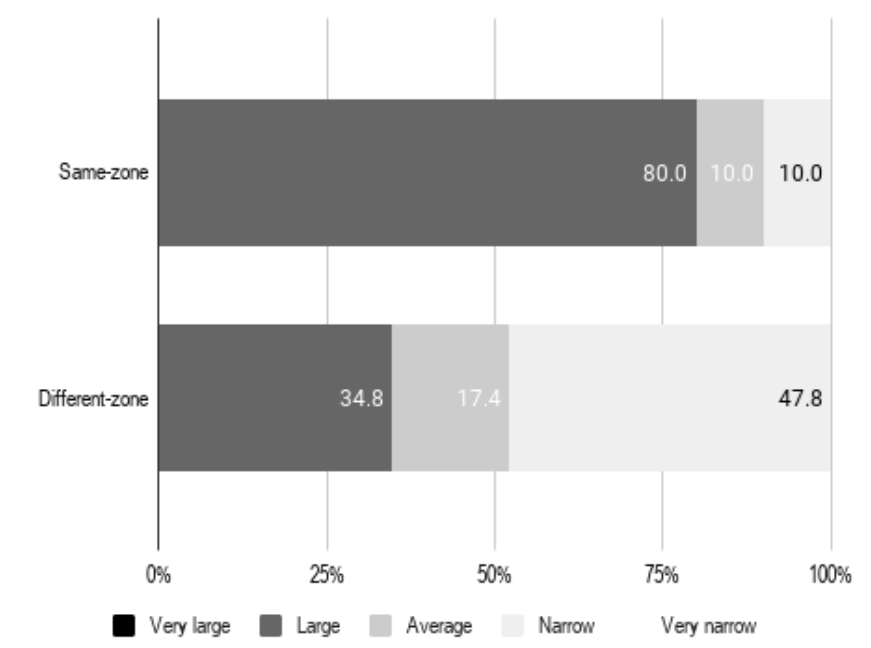

Source: Adapted from Pinheiro (2020)

Finally, the height evaluation also showed a sensible difference in the participants' perceptions. While 50\% of the participants in the same zone as their target viewpoint classified the room as "very high", only $37.5 \%$ of those located in different zones to their target viewpoint had the same perception. As a complementary result, the classification "high" increased from $45.8 \%$ up to $62.5 \%$ from the "same-zone" participants to "different-zone" users.

These results demonstrate that even though the participants could move around the IVE and there was unlimited time to answer the questions, their answers about spatial perception were possibly influenced by their immediate position and target viewpoint when the question was made.

Considering that this is an exploratory study, a qualitative and preliminary statistical analysis was developed. The statistical analysis was developed in IBM SPSS Statistics Data Editor, and there was no gender nor educational level effect ( $p>0.05$ ) across the analyzed variables.

Based on the Shapiro-Wilk test, the width, length and height were not normally distributed $(p<0.05)$ since there were unequal sample sizes in both the length, width and height variables due to the different participants' positions and viewpoints. In order to verify statistically significant differences in the variables, Welch's t-test was adopted instead of one-way Friedman's ANOVA. There was a statistically significant level in width 
and the relation between the participant's position and viewpoint $(p<0.01)$, as shown in Figure 7 .

Figure 7 - Comparison between a one-way ANOVA and a Welch's t-test (preferred in this case, once there was unequal sample sizes)

\begin{tabular}{lr|r|r|r|r}
\multicolumn{7}{c}{ ANOVA } \\
Width & & & & & \\
& & & & & \\
& Sum of Squares & df & Mean Square & \multicolumn{1}{c}{ F } & Sig. \\
\hline Between Groups & 5,232 & 1 & 5,232 & 7,134 &, 011 \\
\hline Within Groups & 27,868 & 38 &, 733 & & \\
\hline Total & 33,100 & 39 & & & \\
\hline
\end{tabular}

\section{Robust Tests of Equality of Means}

Width

\begin{tabular}{rr|r|c|c} 
& Statistic $^{\text {a }}$ & \multicolumn{1}{c}{ df1 } & df2 & Sig. \\
\hline Welch & 8,051 & 1 & 31,627 &, 008 \\
\hline
\end{tabular}

a. Asymptotically $\mathrm{F}$ distributed.

Source: Adapted from Pinheiro 2020.

However, even if there was a qualitative difference within the length and height according to the participants' position and viewpoint, there was no statistically significant difference among the results.

\section{Surfaces' temperature perception}

To analyze the users 'perception of the apparent surface temperature, the users' target viewpoints were mapped inside the white (insolated areas) or gray (shaded areas) zones, as shown in Figure 8. The results show a significant difference between the participants who were currently looking at an exposed point and those who were not. For this analysis, the footbridge surfaces were not mapped due to their small visible surface, and the roof surface was not included due to full exposure to sun rays.

The floor surface and wall surface evaluation results are shown in Figure 9. It demonstrates that among those looking at insolated points of the IVE floor, 57.1\% classified the floor material as "warm", and $42.9 \%$ had the opposite perception. Diversely, only $3 \%$ of those looking at shaded points of the floor evaluated the floor surface as being "warm", while $93.9 \%$ believed it was a cold surface.
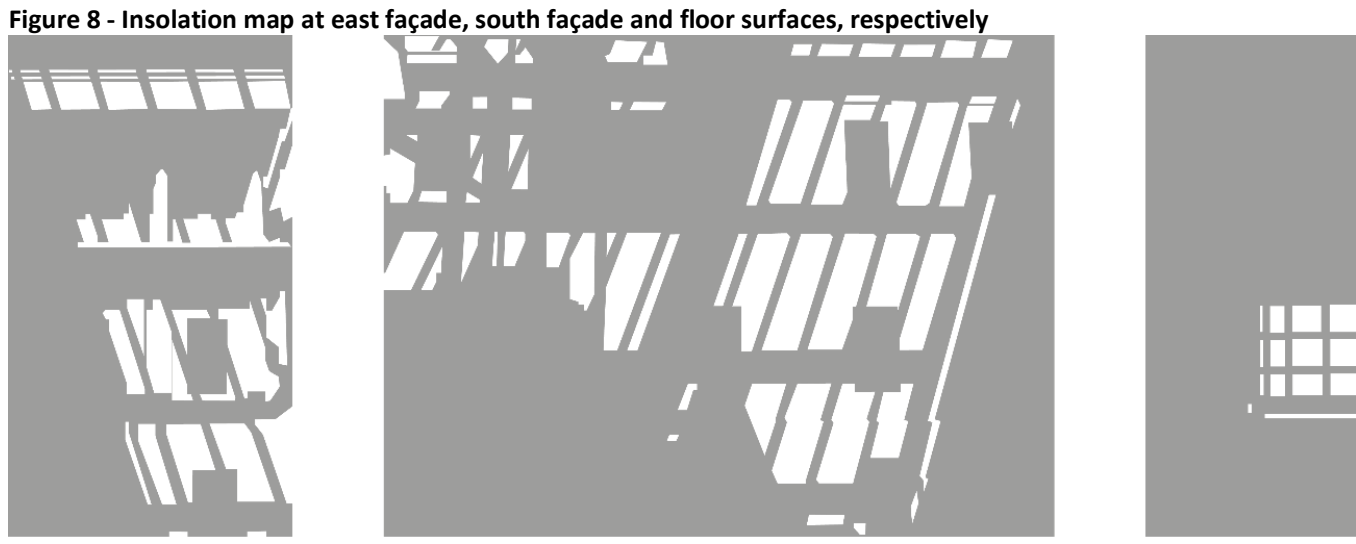

Source: Pinheiro (2020). 
Figure 9 - Sense of apparent temperature of floor (left) and walls (right), according to the user's viewpoint at the time of question 40 respondents
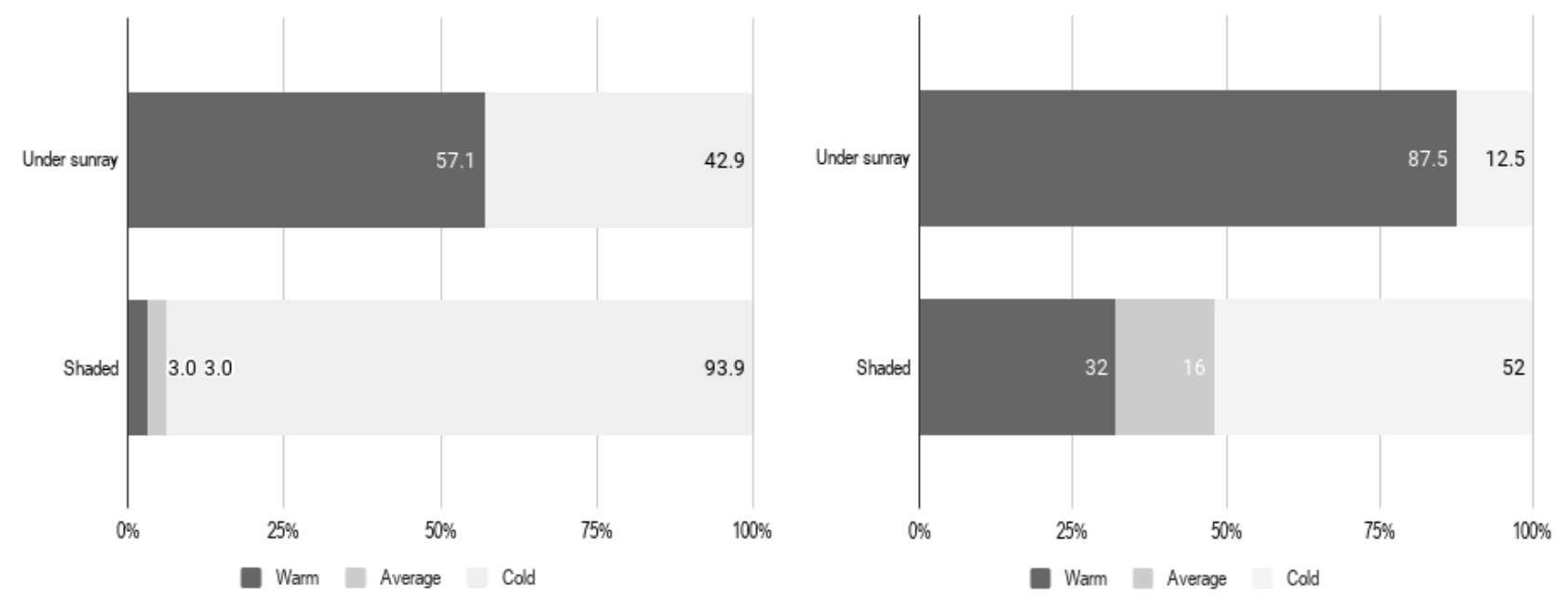

Source: Adapted from Pinheiro (2020)

The results of the wall surface temperature perception presented a similar result. Among the participants looking at insolated points of the IVE, $57.1 \%$ classified the surface as "warm", and only $12.5 \%$ had the opposite perception. When compared to the participants targeting at shaded points, there was a significant difference. Only $32 \%$ of the latter evaluated the wall surfaces as being "warm", while $52 \%$ of the same users concluded the opposite.

The Shapiro-Wilk test showed that none of the virtually perceived surface temperatures was normally distributed $(p<0.05)$. Considering that similarly to the spatial perception, the surface temperature had different sample sizes, Welch's test was adopted instead of one-way Friedman's ANOVA. The results demonstrated that there was a statistically significant difference between participants that classified the floor's apparent temperature and the current viewpoint $(\mathrm{p}<0.05)$, as shown in Figure 10.

In the same way, there was also a significant difference between the wall temperature and respondents' viewpoints $(p<0.05)$. Unlike the spatial answers, the users' perception of the apparent temperature of both floor and walls had statistically significant differences based on the presence of sun rays.

Figure 10 - Sense of floor surface temperature had a statistically significant difference according to the user viewport, whether looking to parts of floor exposed to sunrays or not

\section{Robust Tests of Equality of Means}

FloorTemp

\begin{tabular}{rr|r|c|c} 
& Statistic $^{a}$ & \multicolumn{1}{c}{ df1 } & df2 & \multicolumn{1}{c}{ Sig. } \\
\hline Welch & 6,597 & 1 & 6,333 &, 040 \\
\hline
\end{tabular}

a. Asymptotically F distributed.

Source: Adapted from Pinheiro (2020).

\section{Resemblance questionnaire}

Finally, a resemblance questionnaire was distributed to the participants to assess similarities and differences between the virtual and the built north atrium of the Pinacoteca building. Since it represents exploratory research where the same users were asked to experience the virtual and the physically correlated north atrium, an IPQ 
PINHEIRO, P. S. J.; ORNSTEIN, S. W.; SHIMOMURA, A. R. P.

User environment perception in HMD-based immersive virtual reality context

was not mandatory (SCHUBERT, 2003). A comparison between the virtual version of the north atrium and the existing atrium is depicted in Figure 11.

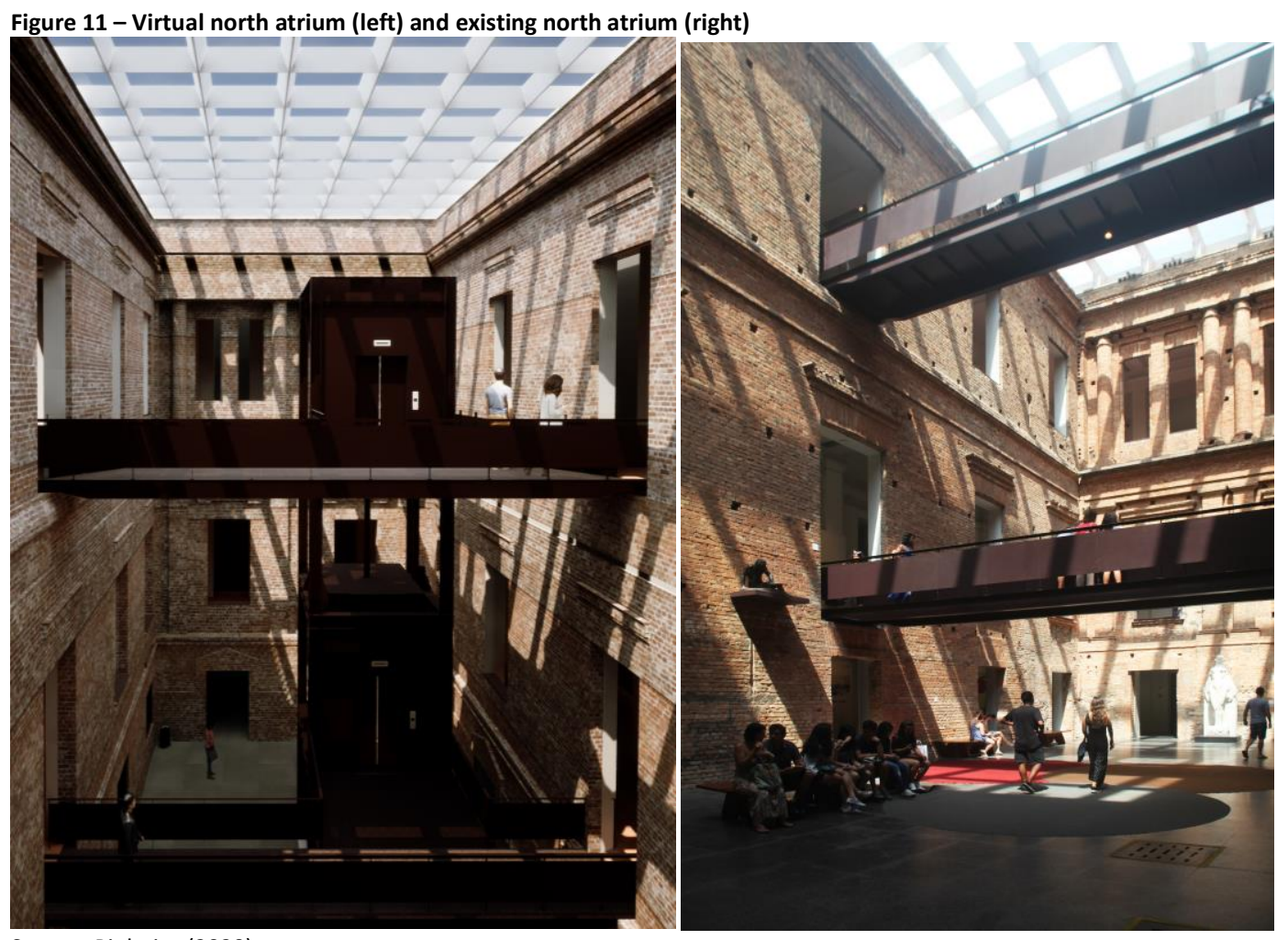

Source: Pinheiro (2020).

This section aimed to verify whether there was a correlation between the participants' position or viewpoint and the resemblance assessment. The results of the resemblance questionnaire are shown in Figure 12.

Figure 12 - Resemblance between the virtual and the actual built north atrium, according to the participants 39 respondents

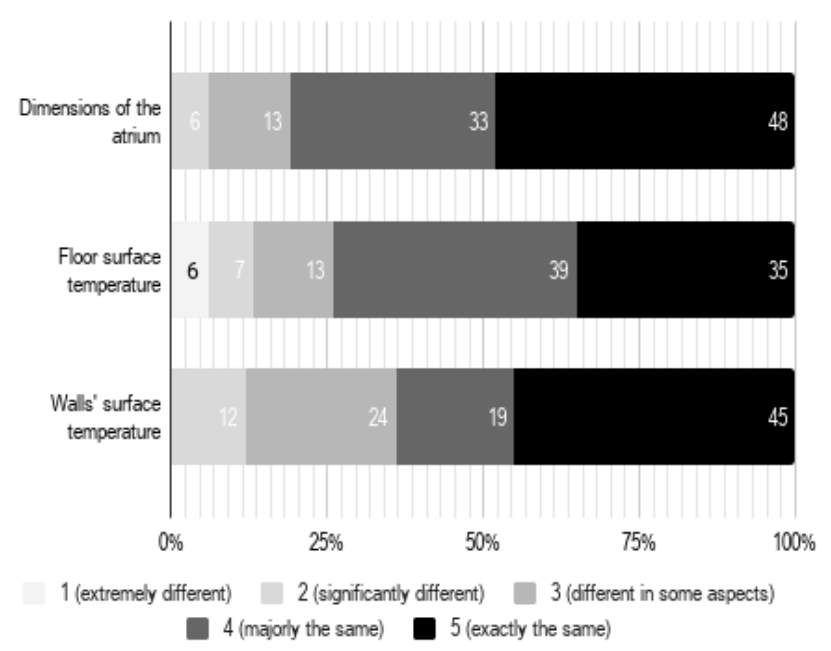

Source: Pinheiro (2020)

The results of resemblance between the virtual and the built north atrium show that the participants classified the IVE as most similar to the built north atrium in most cases. For this analysis, one problematic case was identified and removed from the dataset, resulting in 39 participants for this section. 
Even though there was a big deviation among the assessments, the overall resemblance evaluation results were positive, considering that 5 (the same) factor was the most answered by the participants when comparing the dimensions of both rooms (median 4.2), as well as the wall surface temperature correlation (median 4). The median was lower than the other evaluation aspects (3.9) for the floor temperature and a higher deviation. For this element, the most cited factor was 4 (majorly similar).

There was no correlation between the participants' position or viewpoint and the resemblance questionnaire evaluation $(p>0.05)$. This result shows that, although the perceived space and apparent surface temperature were influenced by the user's position and point of view at the time of the question, this aspect did not influence the assessment of similarity between the virtual and constructed versions of the atrium. These results endorse previous studies showing that HIVEs are an efficient tool to reproduce the built environment, such as Maffei et al. (2016) that investigated the resemblance of this kind of technology in urban space with multisensory stimuli.

\section{Discussion}

This paper presents an exploratory study investigating spatial perception and the sense of the surface temperature of users in HIVE and possible correlation factors. The results show that the two main effects on users' perception may be related to immediate conditions when the questions were asked. Even though the HIVE is often associated with a dynamic way of perceiving the built environment once the user can freely move around the virtual room with a strong sense of presence (SCHUBERT, 2003), the results show that both spatial (width specifically) and surface temperature perception were significantly influenced by instant aspects of modelling and user position or viewpoint.

Even though the participants rated the virtual version as most similar to the built north atrium of the Pinacoteca building, this study suggests that the results of the building evaluation using similar VR tools may be biased by immediate responses.

As demonstrated in the results, the participants' immediate position and viewpoint at the time of the question had a statistically significant effect on the results of width perception. Users located closer to their target viewpoint (classified in this study as same-zone users) tended to evaluate the virtual north atrium as a wider room. In contrast, the users located in further positions to their target viewpoint (classified in this study as different-zone users) tended to assess the same room as a narrower room. The results also dialogue with Renner, Velichkovsky, and Helmert (2013), who reported that HIVE has accounted for a certain amount of distance compression of users' subjective egocentric distance from the actual distance.

Similarly to the spatial assessment, the sense of the surface temperature of the atrium was also affected by the insolation conditions of the IVE. Users that evaluated the virtual room textures by the sunlight tended to evaluate a virtual surface texture as warmer than those who evaluated the same material in the shade. As both floor and wall textures had the same effect, this study suggests that regardless of the type of material, the presence of heatstroke in HIVEs can influence users' perceptions when applying verbal assessment questionnaires.

As the first contribution for including VR technologies as a tool for design development, this study indicated the impact of an immediate virtual situation on the users' perception of spatial and surface temperature in HIVE. Secondly, considering that user's sense of temperature is not only a single correlation to the actual physical temperature, but considered as multi-sensorial stimuli (LAM et al., 2020), understanding the sense of surface temperature by users in HIVE is also extremely important regarding the way that 
users evaluate a virtual room in VR. The second contribution of this paper is to investigate how the users' sense of surface temperature correlates to their immediate position and target viewpoint when the question is made. These findings can lead to important design decisions while modelling and texturing future IVEs and questionnaires to assess users' perception of spatial or apparent surface temperature in immersive environments.

Due to the different numbers between male and female participants $(26 \mathrm{M} / 14 \mathrm{~F})$, no comparative analysis of data between genders was performed in the dimensions and perception of surface temperature assessments. Even so, some biases in this exploratory research can be caused by the gender composition of the sample. Further investigation is needed to generalize results for female participants, as their contribution in this research was significantly lower than that of male participants.

Pinheiro (2020) demonstrated that the north atrium is a transitional space, and visitors spend a very short time in the evaluated room, so the results may not be replicable to long-stay spaces. In addition, the way the questions were applied through verbal questionnaires may have resulted in biases caused by the short time for users to respond and the fact that the participants had to say the results aloud. Ono et al. (2018) show that verbal and traditional questionnaires may infer different outcomes in the POE procedures.

The main outcomes of this study were that there is evidence that their position and viewpoint influence users' perception in IVE when the questions were asked. This result is aligned with techniques applied in cinema and photography. It may establish new connections between these two forms of art to architecture even if the immersed user can walk without a predetermined path. As this was an exploratory study, further investigation is recommended on the replicability of the findings with more participants and equivalent gender distribution.

Future studies with different assessment tools may also bring more information towards immediate users' spatial and surface temperature evaluation without possible biases caused by verbal questionnaires. It is also recommended to spend more time evaluating procedures of comparison with the present study's findings. Also, another important future research to be developed based on the outcomes of this research would be to compare the behavior of users once in non-transitional rooms, such as living spaces workspaces or classrooms.

\section{Conclusion}

An effective way to include end-users in architectural design assessment procedures has been to use HIVE (KOUTSABASIS et al., 2012). Architects have constantly used this widespread technology to evaluate projects and communicate with customers and other designers during initial design phases to avoid future corrections in the built environment. It can be a tool to minimize the need for corrections and adjustments in the most advanced stages of the project or even during construction (ONO et al., 2018).

In the present study, an investigation was conducted on users' perception of spatial dimensions and surface temperature in HIVE. In an exploratory way, the effects of the immediate position and viewpoint of users in IVE were indicated by the procedures conducted with 40 volunteer participants that experienced a virtual version of the north atrium of the Pinacoteca building.

These findings have a relevant contribution to architectural design evaluation when considered that introducing HIVE as an assessment tool should also include the control 
of its possible biases. As exploratory research, this study opens up new discussions about using HIVE systematically in design review procedures and indicates possible influences in the way users perceive virtual environments. The HIVE experimentation time was brief, therefore for future studies, longer immersion times and shorter questionnaires would be more effective procedures to avoid bias in design assessment procedures.

Knowing that users' answers towards spatial perception are potentially influenced by their immediate position and target viewpoint can lead to new practices and further studies that consider this a possible variable. Similarly, knowing the effects of light on the immediate perception of surface temperature will help the development of more realistic models, as well as more accurate protocols for design evaluation, considering a longer immersion time in HIVE. Moreover, this study aimed to broaden knowledge about HIVEs and study possibilities of including this tool in the design review process.

\section{Acknowledgements}

The authors would like to thank the staff from the Pinacoteca do Estado de São Paulo for their support in the research and CNPq (process number 304131/2020-2) for the scholarship given to Sheila Walbe Ornstein. The authors also extend their thanks to the volunteer participants of the study.

\section{References}

AIDAR, G.; CHIOVATO, M. Interligar o museu e seu entorno: a ação educativa extramuros da Pinacoteca do Estado de São Paulo. Revista de Ciências da Educação, São Paulo, n. 25 - ano XIII, p. 1-21, 2012. Available at: http://www.revista.unisal.br/ojs/index.php/educacao/issue/view/11.

BULLINGER, H.; BAUER W.; WENZEL G.; BLACH R. Towards user centered design (UCD) in architecture based on immersive virtual environments. Computers in Industry, v.61, n.4, p. 372-379, 2010. DOI:

https://doi.org/10.1016/j.compind.2009.12.003.

CARNEIRO, J. P.; ARYAL, A.; BECERIK-GERBER, B. Influencing occupant's choices by using spatiotemporal information visualization in Immersive Virtual Environments. Building and Environment, v.150, p.330-338, 2019. DOI: https://doi.org/10.1016/j.buildenv.2019.01.024.

CHA, S. H.; CHOONGWAN KOO; KIM, T. W.; Hong, T. Spatial perception of ceiling height and type variation in immersive virtual environments. Building and Environment, v.163, p. 1-10, 2019. DOI:

https://doi.org/10.1016/j.buildenv.2019.106285.

CHAMILOTHORI, K.; CHINAZZO, G.; RODRIGUES, J.; DAN-GLAUSER, E.S.; WIENOLD, J.; ANDERSEN, M. Subjective and physiological responses to facade and sunlight pattern geometry in virtual reality. Building and Environment, v.150, p. 144-155, 2019. DOI: https://doi.org/10.1016/j.buildenv.2019.01.009.

CIALONE, C.; TENBRINKS, T.; SPIERS, H. J. Sculptors, Architects, and Painters Conceive of Depicted Spaces Differently. Cognitive Science, vol. 42, issue 2, 2018. DOI:

https://onlinelibrary.wiley.com/action/showCitFormats?doi=10.1111\%2Fcogs.12510.

DUNSTON, P.S.; ARNS, L.L.; MCGLOTHLIN, J.D.; LASKER, G.C.; KUSHNER, A.G. An Immersive Virtual Reality Mock-Up for Design Review of Hospital Patient Rooms. In: WANG, X.; TSAI, J.J.-H. (ed.) Collaborative Design in Virtual Environments. Intelligent Systems, Control and Automation: Science and Engineering, v. 48. Springer, Dordrecht, 2011.DOI: https://doi.org/10.1007/978-94-007-0605-7_15.

FAAS, D.; BAO, Q.; FREY, D. D.; YANG, M. C. The influence of immersion and presence in early stage engineering designing and building. Design Computing and Cognition, v.28, p. 139-151, 2014. DOI:

https://doi.org/10.1017/S0890060414000055. 
FISHER-GEWIRTZMAN, N. D. Visibility of urban activities and pedestrian routes: An experiment in a virtual environment. Computers Environment and Urban Systems, v.58, p. 60-70, 2016. DOI: https://doi.org/10.1016/j.compenvurbsys.2016.03.007.

FLORIO, W.; TAGLIARI, A. Modelagem e animação para análise de espaços em projetos não construídos. PARC Pesquisa em Arquitetura e Construção, Campinas, SP, v. 7, n. 2, p. 61-74, 2016. DOI: https://doi.org/10.20396/parc.v7i1.8643565.

FREITAS, M. R.; RUSCHEL, R. C. Aplicação de realidade virtual e aumentada em arquitetura. Arquitetura Revista, v. 6, n 2:127-135, 2010. DOI: https://doi.org/10.4013/4553.

HEYDARIAN, J. P. C.; GERBER, D.; BECERIK-GERBER, B. Immersive virtual environments, understanding the impact of design features and occupant choice upon lighting for building performance. Building and Environment, v.89, p. 217-228, 2015.DOI: https://doi.org/10.1016/j.buildenv.2015.02.038.

JULEAN, D. Why Architects See Things Differently an Architectural Approach On Teaching Space Perception. European Scientific Journal, v.special, p. 1-10. April 2016. Available at: http://eujournal.org/index.php/esj/article/viewFile/7351/7071.

KIM, H. K.; PARK, J.; CHOI, Y.; CHOE M. Virtual reality sickness questionnaire (VRSQ): Motion sickness measurement index in a virtual reality environment. Applied Ergonomics, V. 69, p. 66-73, 2018. DOI:

https://doi.org/10.1016/j.apergo.2017.12.016.

KLERK, R.; DUARTE, A. M.; MEDEIROS, D. P.; DUARTE, J. P.; JORGE, J.; LOPES, D. S. Usability studies on building early stage architectural models in virtual reality. Automation in Construction, v.103, p. 104-116, 2019. DOI: https://doi.org/10.1016/j.autcon.2019.03.009.

KOUTSABASIS, P.; VOSINAKIS, S.; MALISOVA, K.; PAPAROUNAS, N. On the value of Virtual Worlds for collaborative design. Design Studies, v. 33, n.4, p. 357-390, 2012. DOI: https://doi.org/10.1016/j.destud.2011.11.004.

KULIGA, S.F.; THRASH, T.; DALTON, R.C.; HOLSCHER, C. Virtual reality as an empirical research tool — exploring user experience in a real building and a corresponding virtual model. Computers, Environment and Urban Systems, v.54, p. 363-375, 2015. DOI: https://doi.org/10.1016/j.compenvurbsys.2015.09.006.

LAM, C. K. C.; YANG, H.; YANG, X.; LIU, J.; CUI, C.O.S.; KONG, X.; HANG, J. Cross-modal effects of thermal and visual conditions on outdoor thermal and visual comfort perception. Building and Environment, v.186, p. 1-23, 2020. DOI: https://doi.org/10.1016/j.buildenv.2020.107297.

MAFFEI, L.; MASULLO, M.; PASCALE, A.; RUGGIERO, G.; ROMERO, V. P. Immersive virtual reality in community planning: Acoustic and visual congruence of simulated vs real world. Sustainable Cities and Society, v.27, p. 338345, 2016.DOI: http://dx.doi.org/10.1016/j.scs.2016.06.022.

OLIVEIRA, Alessandra Arenales Salgado de. Utilização da animação computacional na verificação do programa arquitetonico de necessidades. 2003. 154p. Dissertação (mestrado) - Universidade Estadual de Campinas, Faculdade de Engenharia Civil, Campinas, SP. Disponível em: http://www.repositorio.unicamp.br/handle/REPOSIP/257881 .

ONO R.; ORNSTEIN, S. W.; VILLA, S. B.; FRANÇA A. J. G. L. Avaliação Pós-Ocupação na Arquitetura, no Urbanismo e no Design: da teoria à prática. São Paulo: Oficina de Textos, 2018.

PAES, D.; ARANTES, E.; IRIZARRY, J. Immersive environment for improving the understanding of architectural 3D models: Comparing user spatial perception between immersive and traditional virtual reality systems. Automation in Construction, v.84, p. 292-303, 2017. DOI: https://doi.org/10.1016/j.autcon.2017.09.016.

PINHEIRO, Pedro Sávio Jobim. Realidade virtual como ferramenta de avaliação de projetos de arquitetura: uma experiência museológica. 2020. Dissertação (Mestrado em Tecnologia da Arquitetura) - Faculdade de Arquitetura e Urbanismo, Universidade de São Paulo, São Paulo, 2020 
RENNER, R. S.; VELICHKOVSKY, B. M.; HELMERT, JENS R. The Perception of Egocentric Distances in Virtual Environments - A Review. ACM Computing Surveys, 46, 2013, p. 1-40. DOI: https://doi.org/10.1145/2543581.2543590.

SCHUBERT, T. The sense of presence in virtual environments: A three-component scale measuring spatial presence, involvement, and realness. Zeitschrift fur Medienpsychologie, v.15, p.69-71, 2003. DOI: https://econtent.hogrefe.com/doi/10.1026//1617-6383.15.2.69.

SHEN, W.; ZHANG, X.; QIPING SHEN, G.; FERNANDO, T. The User Pre-Occupancy Evaluation Method in designerclient communication in early design stage: A case study. Automation in Construction, v.32, p. 112-124, 2013. DOI: https://doi.org/10.1016/j.autcon.2013.01.014.

SHUSHAN, Y.; PORTUGALI, J.; BLUMENFELD-LIEBERTHAL, E. Using virtual reality environments to unveil the imageability of the city in homogenous and heterogeneous environments. Computers Environment and Urban Systems, v.58, p. 29-38, 2016. DOI: https://doi.org/10.1016/j.compenvurbsys.2016.02.008.

SOUZA, M. P.; IMAI, C.; AZUMA, M. H. Contribuições e limitações de modelos físicos e de RV na análise de projetos de HIS por usuários leigos. Gestão e Tecnologia de Projetos, São Carlos, v.13 n.3. São, 2018. DOI: http://dx.doi.org/10.11606/gtp.v13i3.146376.

WITMER, B. G.; SADOWSKI JR, W.J. Nonvisually Guided Locomotion to a Previously Viewed Target in Real and Virtual Environments. Human Factor, v.40, n.3, 1998. DOI: https://doi.org/10.1518/001872098779591340.

YEOM, D.; CHOI, J.; KANG, S. H. Investigation of the physiological differences in the immersive virtual reality environment and real indoor environment: Focused on skin temperature and thermal sensation. Building and Environment, v.154, p. 44-54, 2019. DOI: https://doi.org/10.1016/j.buildenv.2019.03.013.

ZHANG, Y.; LIU, H.; KANG, S-C; AL-HUSSEIN, M. Virtual reality applications for the built environment: Research trends and opportunities. Automation in Construction, v.118, p. 1-19, 2020. DOI:

https://doi.org/10.1016/j.autcon.2020.103311.

\section{${ }^{1}$ Pedro Sávio Jobim Pinheiro}

Arquiteto e Urbanista. Mestre em Arquitetura e Urbanismo pela Faculdade de Arquitetura e Urbanismo da Universidade de São Paulo. Endereço postal: Rua do Lago 876, Cidade Universitária, São Paulo, São Paulo, CEP 05508-080.

\section{Sheila Walbe Ornstein}

Arquiteta e Urbanista. Doutorado em Arquitetura e Urbanismo pela Universidade de São Paulo. Professora Titular na Faculdade de Arquitetura e Urbanismo da Universidade de São Paulo. Endereço postal: Rua do Lago 876, Cidade Universitária, São Paulo, São Paulo, CEP 05508-080.

\section{${ }^{3}$ Alessandra Rodrigues Prata Shimomura}

Arquiteta e Urbanista. Doutorado em Arquitetura e Urbanismo pela Universidade de São Paulo. Professora Doutora da Faculdade de Arquitetura e Urbanismo da Universidade de São Paulo. Endereço postal: Rua do Lago 876, Cidade Universitária, São Paulo, São Paulo, CEP 05508-080. 